\title{
Nurses and the administration of Adrenaline in anaphylactic shock following the application of IV medicine
}

\author{
Rudolf Scheller ${ }^{1 *}$, Stefan Posth ${ }^{2}$ \\ From 6th Danish Emergency Medicine Conference \\ Odense, Denmark. 20-21 November 2014
}

"We recommend first-line treatment with intramuscular
adrenaline before instituting other interventions as adrena-
line is still underutilized in anaphylaxis although it is
potentially lifesaving."
EAACI Guidelines Anaphylaxis 2014

How is reality in a Danish university hospital?

At Odense University Hospital, nurses take part in a simulation training in critical patient care for younger doctors. One of the scenarios used is anaphylactic shock after the application of IV antibiotics. 49 out of 50 nurses realized within the first two minutes, that the simulation patient suffered from anaphylaxis. 48 out of 50 nurses stopped the IV with the antibiotic. Often, oxygen and IV $\mathrm{NaCl}$ was administered, and thereafter the doctor, who was five minutes away was called. Only two out of 50 nurses primarily injected adrenalin according to the hospital guideline.

Because of this, in 48 out of 50 cases adrenalin was given after more than five minutes. According to Pumphrey (2000), the median for a deadly anaphylactic reaction after the IV administration of medication is five minutes. Adrenalin is according to EAACI Guidelines 2014 and ERC Guidelines 2010 the primary treatment for anaphylactic shock and the only treatment that is lifesaving in such a situation.

\section{Conclusion}

It is necessary for all nurses to receive training in anaphylactic shock, including the primary injection of adrenalin in order to secure immediate treatment in this critical condition.

\footnotetext{
* Correspondence: rudolf.scheller@rsyd.dk

'Department of Geriatric Medicine, OUH Odense University Hospital, Odense, Denmark

Full list of author information is available at the end of the article
}

This training could be linked to resuscitation training.

\section{Authors' details}

'Department of Geriatric Medicine, OUH Odense University Hospital, Odense, Denmark. ${ }^{2}$ Department of Emergency Medicine, OUH Odense University Hospital, Odense, Denmark.

Published: 16 July 2015

\section{doi:10.1186/1757-7241-23-S1-A45}

Cite this article as: Scheller and Posth: Nurses and the administration of Adrenaline in anaphylactic shock following the application of

IV medicine. Scandinavian Journal of Trauma, Resuscitation and Emergency Medicine 2015 23(Suppl 1):A45.
Submit your next manuscript to BioMed Central and take full advantage of:

- Convenient online submission

- Thorough peer review

- No space constraints or color figure charges

- Immediate publication on acceptance

- Inclusion in PubMed, CAS, Scopus and Google Scholar

- Research which is freely available for redistribution

Submit your manuscript at www.biomedcentral.com/submit
() Biomed Central 